\title{
Profiling Methodist leadership
}

\section{Leslie Francis and Adam Stevenson}

The Revd Canon Professor Leslie J. Francis is Director of the Warwick Religions and Education Research Unit, University of Warwick, and Honorary Distinguished Canon, Manchester Cathedral.

leslie.francis@warwick.ac.uk Warwick, UK

The Revd Adam J. Stevenson is a Presbyter in The Fens circuit and part of the Warwick Religions and Education Research Unit, University of Warwick, working on his PhD, 'An ordinary theology of Methodist worship'.

adam.stevenson@methodist.org.uk

Wisbech, UK

This paper explores the similarities and dissimilarities between the psychological type and temperament profiles of Methodist local preachers and Methodist circuit ministers in the British Methodist Church. New data provided by 80 male and 62 female local preachers who completed the Francis Psychological Type Scales were compared with the profiles of 693 male and 311 female ministers published in 2010. The most important significant difference between the two groups concerns the higher proportions of the Epimethean Temperament (SJ) among both the male (69\% compared with 44\%) and female (66\% compared with $43 \%$ ) local preachers. The SJ temperament brings a more conservative and conserving approach to ministry.

PSYCHOLOGICAL TYPE THEORY • KEIRSEY TEMPERAMENT THEORY • CLERGY STUDIES • METHODIST LOCAL PREACHERS 


\section{Introduction}

Methodist circuit ministry in Great Britain today is maintained by the combined efforts of Methodist circuit ministers ordained to presbyteral ministry and of local preachers serving in the circuit (see British Methodism Today by Haley and Francis 2006). Without local preachers, circuit ministry would not be sustainable.

Lay preachers have been a feature of Methodism since its conception. Margaret Batty recounts stories of two early lay preachers, Thomas Westall and Thomas Maxfield, who were permitted to preach by the Wesleys, even though they had reservations about the added difficulties such 'irregularities' may cause their relationship with the Church of England (Milburn and Batty 1995). As Methodism developed, so did the number of lay preachers. In the minutes of meetings held from 1751 onwards it became evident that lay preachers were very much part of Methodism. Then, in 1797, Conference established the Local Preachers' Meeting and a mechanism for checking on the standards of preaching by involving both the superintendent minister and the wider body of local preachers.

The role of local preachers continued to develop, and their status and identity in the various branches of nineteenth-century Methodism was not a consistent picture. After Methodist Union in 1932 local preachers were mainly trained through the study of set textbooks with written examinations administered by the Methodist Church. In 1990 a new training course was launched using local tutors and containing units of study. This 1990 course was only superseded in 2017 by the latest training course that is modular and uses web-based learning. The Local Preachers' Meeting still conducts oral examinations for preachers, at the various stages of development, allowing preachers in training to account for their calling, development and assent to Methodist doctrine. Local preachers are first given a'note' to preach, and during this initial stage they test their calling to this ministry, as does the local Methodist circuit. At the same time, they begin the formal training course on which they are supported by a local tutor and mentor. Local preachers move to being 'on trial' until their training is completed satisfactorily and they are'fully accredited'. Today there are 6,602 fully accredited local preachers, with a further 655 on note and 896 on trial (Methodist Church 2017). Each person is likely to be leading between four and six acts of worship in a quarter according to the Millennial Profile (Sawkins 2002). An individual church, however, could expect half or even three-quarters of its services to be led by local preachers, depending on the ordained resources of the circuit. 
Against this background, the aim of the present study is to report a new empirical survey of the psychological type and temperament profile of local preachers and to set that alongside the profile of Methodist circuit ministers published by Burton, Francis and Robbins (2010). The purpose of the comparison is to test whether local preachers and Methodist circuit ministers bring the same or different psychological preferences and gifts to their leadership of worship and to the life of the local chapel. But first it is necessary to give some broader context to psychological type theory and to temperament theory.

\section{Psychological type theory}

Psychological type theory has its roots in the observations and documentation of human behaviour by Jung (1971) and in the developments shaped by the Myers-Briggs Type Indicator (Myers and McCaulley 1985), the Keirsey Temperament Sorter (Keirsey and Bates 1978) and the Francis Psychological Type Scales (Francis 2005). The basic building blocks of psychological type theory distinguish between two orientations (extraversion and introversion), two perceiving functions (sensing and intuition), two judging functions (thinking and feeling), and two attitudes towards the outer world (judging and perceiving). Francis and Payne (2002) speculated about the implication of these building blocks of psychological type theory for ways in which clergy may prefer to shape and focus their ministry style.

The two orientations are concerned with where energy is drawn from: energy can be gathered either from the outside world or from the inner world. Clergy who prefer extraversion (E) are orientated towards the outside world; they are energised by the events and people around them. They enjoy communicating and thrive in stimulating and exciting environments. They prefer to act in a situation rather than to reflect on it. They may vocalise a problem or an idea, rather than thinking it through privately. They tend to focus their attention upon what is happening outside themselves. They are usually open individuals, easy to get to know, and enjoy having many people around them. In contrast, clergy who prefer introversion (I) are orientated towards their inner world; they are energised by their inner ideas and concepts. They may feel drained by events and people around them. They prefer to reflect on a situation rather than to act in it. They enjoy solitude, silence and contemplation, as they tend to focus their attention upon what is happening in their inner life. They may appear reserved and detached as they are difficult to get to know. 
The perceiving functions are concerned with the way in which people receive and process information; this can be done through use of the senses or through use of intuition. Clergy who prefer sensing ( $S$ ) focus on the realities of a situation as perceived by the senses. They tend to focus on specific details, rather than the overall picture. They are concerned with the actual, the real and the practical, and tend to be down-to-earth and matter-of-fact. They may feel that particular details are more significant than general patterns. They are frequently fond of the traditional and conventional. They may be conservative and tend to prefer what is known and well established. In contrast, clergy who prefer intuition $(\mathrm{N})$ focus on the possibilities of a situation, perceiving meanings and relationships. They may feel that perception by the senses is not as valuable as information gained from the unconscious mind; indirect associations and concepts impact their perceptions. They focus on the overall picture, rather than specific facts and data. They follow their inspirations enthusiastically, but not always realistically. They can appear to be up in the air and may be seen as idealistic dreamers. They often aspire to bring innovative change to established conventions.

The judging functions are concerned with the way in which people make decisions and judgements; this can be done through use of objective impersonal logic or subjective interpersonal values. Clergy who prefer thinking (T) make judgements based on objective, impersonal logic. They value integrity and justice. They are known for their truthfulness and for their desire for fairness. They consider conforming to principles to be of more importance than cultivating harmony. They are often good at making difficult decisions as they are able to analyse problems in order to reach an unbiased and reasonable solution. They are frequently referred to as 'tough-minded'. They may consider it to be more important to be honest and correct than to be tactful, when working with others. In contrast, clergy who prefer feeling $(F)$ make judgements based on subjective, personal values. They value compassion and mercy. They are known for their tactfulness and for their desire for peace. They are more concerned to promote harmony than to adhere to abstract principles. They may be thought of as 'people persons', as they are able to take into account other people's feelings and values in decision-making and problem-solving, ensuring they reach a solution that satisfies everyone. They are often thought of as 'warm-hearted'. They may find it difficult to criticise others, even when it is necessary. They find it easy to empathise with other people and tend to be trusting and encouraging of others. 
The attitudes towards the outside world are concerned with the way in which people respond to the world around them, either by imposing structure and order on that world or remaining open and adaptable to the world around them. Clergy who prefer judging $(J)$ have a planned, orderly approach to life. They enjoy routine and established patterns. They prefer to follow schedules in order to reach an established goal and may make use of lists, timetables or diaries. They tend to be punctual, organised and tidy. They may find it difficult to deal with unexpected disruptions of their plans. Likewise, they are inclined to be resistant to changes to established methods. They prefer to make decisions quickly and to stick to their conclusions once made. In contrast, clergy who prefer perceiving $(P)$ have a flexible, open-ended approach to life. They enjoy change and spontaneity. They prefer to leave projects open in order to adapt and improve them. They may find plans and schedules restrictive and tend to be easy-going about issues such as punctuality, deadlines and tidiness. Indeed, they may consider last-minute pressure to be a necessary motivation in order to complete projects. They are often good at dealing with the unexpected. Indeed, they may welcome change and variety as routine bores them. Their behaviour may often seem impulsive and unplanned.

\section{Temperament theory}

Drawing on the basic building blocks of psychological type theory, Keirsey and Bates (1978) distinguished between four temperaments characterised as SJ, SP, $\mathrm{NT}$ and NF, and to each of these temperaments they ascribe a distinctive name rooted in classic mythology. The Epimethean Temperament characterises the SJ profile, people who long to be dutiful and exist primarily to be useful to the social units to which they belong. The Dionysian Temperament characterises the SP profile, people who want to be engaged, involved and doing something new. The Promethean Temperament characterises the NT profile, people who want to understand, explain, shape and predict realties, and who prize their personal competence. The Apollonian Temperament characterises the NF profile, people who quest for authenticity and for self-actualisation, who are idealistic and who have great capacity for empathic listening. Oswald and Kroeger (1988) built on Keirsey and Bates' (1978) characterisation of the four temperaments to create profiles of how these four temperaments shape four very different styles of religious leadership. 
The Epimethean Temperament (SJ) is styled 'the conserving, serving pastor'. SJ clergy tend to be the most traditional of all clergy temperaments, bringing stability and continuity in whatever situation they are called to serve. They proclaim a single and straightforward faith, committed to down-to-earth rules for the Christian life. They serve as protectors and conservers of the traditions inherited from the past. If change is to take place, it emerges by evolution, not revolution. They excel at building community, fostering a sense of loyalty and belonging. They bring order and stability to their congregations, creating plans, developing procedures and formulating policies; and they are keen that these procedures should be followed. They can be trusted for their reliability, punctuality and efficiency. They are effective pastors, showing particular concern for the young, the elderly and the weak. They are realists who offer practical and down-to-earth solutions to pastoral problems.

The Dionysian Temperament (SP) is styled 'the action-oriented pastor'. SP clergy tend to be the most fun-loving of all clergy temperaments, possessing a compulsive need to be engaged in activity. They have little need for or interest in the abstract, the theoretical and the non-practical aspects of theology and church life. They are flexible and spontaneous people who welcome the unplanned and unpredictable aspects of church life. They can bring the church to life with activities for everyone from cradle to grave. They have a flare for grasping the moment. They are entertainers and performers at heart. They are at their best in a crisis and are good at handling conflict resolution. Their funloving means they enjoy working with children and young people. They are better at starting new initiatives than at seeing things through. SP clergy may be particularly attracted to charismatic worship, responding to the leading of the Holy Spirit, welcoming a free-flowing form that allows for impromptu testimonials, speaking in tongues and spontaneous singing.

The Promethean Temperament (NT) is styled 'the intellectual, competenceseeking pastor'. NT clergy are the most academically and intellectually grounded of all clergy temperaments, motivated by the search for meaning, for truth and for possibilities. They are visionaries who need to excel in all they do, and they tend to push their congregations to excel as well. They enjoy the academic study and analysis of the faith, and may try to run their church as an extension of the seminary. They make great teachers, preachers and advocates for social justice. They look for underlying principles rather than basic applications from their study of Scripture. They see the value of opposing views and strive to allow alternative visions to be heard. They are more concerned with finding truth than with engineering harmony and compromise. NT clergy 
need to be challenged in their ministry and to be able to move from one challenge to the next.

The Apollonian Temperament (NF) is styled 'the authenticity-seeking, relationship-oriented pastor'. NF clergy tend to be the most idealistic and romantic of all clergy temperaments, attracted to helping roles that deal with human suffering. They want to meet the needs of others and to find personal affirmation in so doing. They can be articulate and inspiring communicators, committed to influencing others by touching their hearts. They have good empathic capacity, interpersonal skills and pastoral counselling techniques. They find themselves listening to other people's problems in the most unlikely contexts, and really caring about them. NF clergy tend to be high on inspiration, but lower on the practical down-to-earth aspects of ministry. They are able to draw the best out of people and work well as the catalyst or facilitator in the congregation as long as others are on hand to work with and to implement their vision. They are at their best when leading in people-related projects, such as starting a project for the elderly or for youth. They are most comfortable in unstructured meetings where they are good at facilitating group decisionmaking processes.

\section{Psychological data}

Since the late 1960s there has been an established tradition of empirical research employing psychological type theory among religious professionals in the USA, reported in early studies like Greenfield (1969), Harbaugh (1984), Holsworth (1984), Cabral (1984), Macdaid, McCaulley and Kainz (1986), Bigelow, Fitzgerald, Busk, Girault and Avis (1988), and latterly Francis, Robbins and Wulff (2011), Burns, Francis, Village and Robbins (2013), and Royle, Norton and Larkin (2015). From the late 1980s this tradition has also flourished in the UK, including studies among Presbyterian Church of Scotland ministers (Irvine 1989), Anglican clergymen serving in the Church in Wales (Francis, Payne and Jones 2001), male and female Bible College students (Francis, Penson and Jones 2001), evangelical church leaders (Francis and Robbins 2002), male missionary personnel (Craig, Horsfall and Francis 2005), evangelical lay church leaders (Francis, Craig, Horsfall and Ross 2005), Roman Catholic priests (Craig, Duncan and Francis 2006), youth ministers (Francis, Nash, Nash and Craig 2007), Anglican clergymen and clergywomen serving in the Church of England (Francis, Craig, Whinney, Tilley and Slater 2007), Assemblies of God theological 
college students (Kay and Francis 2008; Kay, Francis and Craig 2008), lead elders serving within the Newfrontiers network of churches (Francis, Gubb and Robbins 2009), and leaders within the Apostolic networks (Kay, Francis and Robbins 2011).

The first attempt to draw up psychological type profiles of Methodist ministers was published by Burton, Francis and Robbins (2010). They drew on data provided by samples of 693 male ministers and 311 female ministers who completed the 40-item Francis Psychological Type Scales (Francis, 2005) as part of a substantial postal survey. The core findings from this study are presented in Table 1 alongside comparable data on Church of England clergy provided by samples of 626 clergymen and 237 clergywomen published by Francis, Craig, Whinney, Tilley and Slater (2007).

Table 1: Psychological type and temperament profiles of Methodist ministers and Church of England clergy

\section{Clergymen Clergywomen \\ $\mathrm{C}$ of $\mathrm{E}^{1} \quad$ Methodist $^{2} \quad \mathrm{Cof}^{\mathrm{B}}$ Methodist $^{4}$

$\% \quad \% \quad \%$

Psychological type

$\begin{array}{lllll}\text { Introversion (I) } & 57 & 61 & 54 & 53 \\ \text { Intuition (N) } & 62 & 46^{* *} & 65 & 48^{* * *} \\ \text { Feeling (F) } & 54 & 64^{* * *} & 74 & 77 \\ \text { Judging (J) } & 68 & 70 & 65 & 70\end{array}$

Psychological temperament

$\begin{array}{lrlrc}\text { Epimethean (SJ) } & 31 & 44^{* * *} & 29 & 43^{* * *} \\ \text { Dionysian (SP) } & 7 & 10 & 6 & 9 \\ \text { Promethean (NT) } & 27 & 18^{* * *} & 15 & 12 \\ \text { Apollonian (NF) } & 35 & 28^{* *} & 50 & 36^{* *}\end{array}$

${ }^{1}$ From Francis, Craig, Whinney, Tilley and Slater (2007), N = 626

${ }^{2}$ From Burton, Francis and Robbins (2010), N = 693

${ }^{3}$ From Francis, Craig, Whinney, Tilley and Slater (2007), N = 237

${ }^{4}$ From Burton, Francis and Robbins (2010), N = 311 
The first conclusion to emerge from these data concerns the psychological type profile of Methodist circuit ministers. In terms of orientation, the preference among both male and female ministers is for introversion ( $61 \%$ of men and $53 \%$ of women). These are people who may feel more at ease in their study and dealing with individuals and small groups of people than with social events and meeting strangers. In terms of the perceiving process, there is balance between intuition and sensing, with a slight preference for sensing (54\% of men and $52 \%$ of women). The sensing types may be better at careful maintenance and the intuitive types at innovative developments. In terms of the judging process, there is a clear preference for feeling among both male and female ministers (64\% of men and $77 \%$ of women). What is notable here is the contrast with the UK population as a whole where $35 \%$ of men and $70 \%$ of women prefer feeling (Kendall 1998). Here is a church led by both men and women who display a strongly feminine profile in terms of the ways in which they reach decisions and form evaluations. These are people who may feel more comfortable promoting peace and harmony than tackling tough decisions and sorting out interpersonal difficulties within the local church. These are people who may thrive in an environment shaped by women but feel less at home in an environment shaped by men. In terms of their attitudes towards the outer world, there is a clear preference for judging (70\% of men and $70 \%$ of women). Here are people who are more at home in a well-organised and structured environment than one that requires flexibility and spontaneity.

The second conclusion to emerge from these data concerns the points at which there are significant differences, in a statistical sense, between the psychological type profiles of Methodist ministers and Church of England clergy. In terms of the men, there are two statistically significant differences. The Anglican clergymen are more inclined to prefer intuition than the male Methodist ministers $(62 \%$ compared with $46 \%, p<.001)$. This suggests that the Anglican clergymen are more likely to be imaginative and innovative leaders. The Anglican clergymen are more inclined to prefer thinking than male Methodist ministers ( $46 \%$ compared with $36 \%, p<.001$ ). This suggests that the Anglican clergymen are somewhat more likely to take tough management decisions when necessary, although the preference for thinking still remains much lower among Anglican clergymen than among men in general ( $46 \%$ compared with $65 \%)$. In terms of the women, there is one statistically significant difference. Like the situation among the men, the Anglican clergywomen are more inclined to prefer intuition than female Methodist ministers (65\% compared with $48 \%, p<.001)$. 
The third conclusion to emerge from these data concerns the temperament profile of Methodist circuit ministers. Among both male and female ministers the most prevalent profile is the Epimethean Temperament (SJ), with $44 \%$ of men and $43 \%$ women. This is the temperament characterised by Oswald and Kroeger (1988) as'the conserving, serving pastor'. Among both male and female ministers the second most prevalent profile is the Apollonian Temperament (NF), with $28 \%$ of men and $36 \%$ of women. This is the temperament characterised by Oswald and Kroeger (1988) as 'the authenticity-seeking, relationship-oriented pastor'. Among Methodist circuit ministers the other two temperaments are less in evidence.

The fourth conclusion to emerge from these data concerns the points at which there are significant differences, in a statistical sense, between the temperament profiles of Methodist ministers and Church of England clergy. The Anglican clergymen are less inclined to prefer the Epimethean (SJ) Temperament (31\% compared with $44 \%, p<.001)$, more inclined to prefer the Promethean (NT) Temperament (27\% compared with 18\%, $p<.001)$ and more inclined to prefer the Apollonian (NF) Temperament (35\% compared with $28 \%$, $p<.01)$. The Anglican clergywomen are less inclined to prefer the Epimethean (SJ) Temperament $(29 \%$ compared with $43 \%, p<.001)$ and more inclined to prefer the Apollonian (NF) Temperament (50\% compared with $36 \%, p<.01$ ).

\section{Research question}

Against this background the aim of the present study is to explore the psychological type profiles and temperament profiles of male and female local preachers and to set those profiles alongside the data reported by Burton, Francis and Robbins (2010) on Methodist circuit ministers. A comparison of this nature builds on the comparison made by Francis, Jones and Robbins (2014) between Church of England clergy and Readers, the nearest equivalent within the Anglican Church to local preachers within the Methodist Church. In that study the data demonstrated significant psychological similarities, as well as some significant psychological differences, between those exercising Reader ministry and those exercising ordained ministry. The present study sets out to ascertain whether a similar situation appertains within the Methodist Church. 


\section{Method}

\section{Procedure}

A sample of local preachers serving within the four circuits in four different districts (Wales, Manchester and Stockport, Wolverhampton and Shrewsbury, Leeds) were invited to participate in the survey. Usable responses were received from 80 men and 62 women.

\section{Instrument}

Psychological type was assessed by the Francis Psychological Type Scales (FPTS: Francis 2005). This 40-item instrument comprises four sets of ten forced-choice items related to each of the four components of psychological type: orientation (extraversion or introversion), perceiving process (sensing or intuition), judging process (thinking or feeling), and attitude towards the outer world (judging or perceiving). Recent studies have demonstrated this instrument to function well among clergy. For example, Francis and Village (2012) reported alpha coefficients (internal consistency reliability) of .84 for the El scale, .74 for the SN scale, .68 for the TF scale, and .74 for the JP scale.

\section{Participants}

Among the 142 participants in the survey ( 80 men and 62 women), 10\% were under the age of forty, $25 \%$ were in their forties or fifties, $28 \%$ were in their sixties, $29 \%$ were in their seventies, and $8 \%$ were in their eighties; $90 \%$ were fully accredited and $10 \%$ were on note or on trial.

\section{Analysis}

The scientific literature concerned with psychological type (and by extension with psychological temperament) has developed a distinctive way of presenting type-related data. The conventional format of 'type tables' has been used in the present paper to allow the findings from this study to be compared with other relevant studies in the literature. In the two type tables in this paper the profiles of male and female local preachers are compared with the profiles of male and female Methodist circuit ministers as reported by Burton, Francis and Robbins (2010). In these tables the statistical significances of differences in the profiles of different groups (namely local preachers and Methodist circuit ministers) is tested by the means of the Selection Ratio Index (I), an extension of the classic chi-square test (McCaulley 1985). The tables present the data on local preachers (Table 2 on men and Table 3 on women) and compare these 
data with full data on clergy published by Burton, Francis and Robbins (2010). Although these comparative data (on which the tests of statistical significance are based) are not retrievable from the tables themselves, the relevant comparative data are included in the narrative of the text.

\section{Results}

The Francis Psychological Type Scales demonstrated satisfactory levels of internal consistency reliability among the preachers, generating the following alpha coefficients for the El scale, .79; for the SN scale, .70; for the TF scale, .72; and for the JP scale, .74.

Table 2 presents the psychological type profile of the 80 male local preachers and compares them with the psychological type profile of the 693 male Methodist circuit ministers provided by Burton, Francis and Robbins (2010). These data will be discussed in two steps.

The first step discusses the psychological type profile of the male local preachers. In terms of the dichotomous preferences they display preferences for introversion (56\%) over extraversion (44\%), for sensing (73\%) over intuition (28\%), for thinking (51\%) over feeling (49\%), and for judging (85\%) over perceiving $(15 \%)$. In terms of dominant type preferences, they display the following hierarchy: dominant sensing (43\%), dominant feeling (21\%), dominant thinking (20\%), and dominant intuition (16\%). In terms of the 16 complete types, the most frequently occurring types are ISFJs (20\%), ISTJs (19\%) and ESFJs (16\%). In terms of psychological temperament preferences, the most frequently occurring temperament is SJ (69\%), followed by NT (18\%), NF (10\%) and SP (4\%).

The second step compares the psychological profile of the male local preachers with the male Methodist circuit ministers published by Burton, Francis and Robbins (2010). In terms of the dichotomous preferences there are three significant differences between the two groups. While $54 \%$ of the male ministers preferred sensing, the proportion rose to $73 \%$ among the local preachers; while $36 \%$ of the male ministers preferred thinking, the proportion rose to $51 \%$ among the local preachers; while $70 \%$ of the male ministers preferred judging, the proportion rose to $85 \%$ among the local preachers. The difference in terms of the perceiving process is also reflected in the psychological temperament: while $44 \%$ of the male ministers preferred the Epimethean Temperament (SJ), the proportion rose to $69 \%$ among 
Table 2: Type distribution for male local preachers compared with male Methodist circuit ministers reported by Burton, Francis and Robbins (2010)

The sixteen complete types

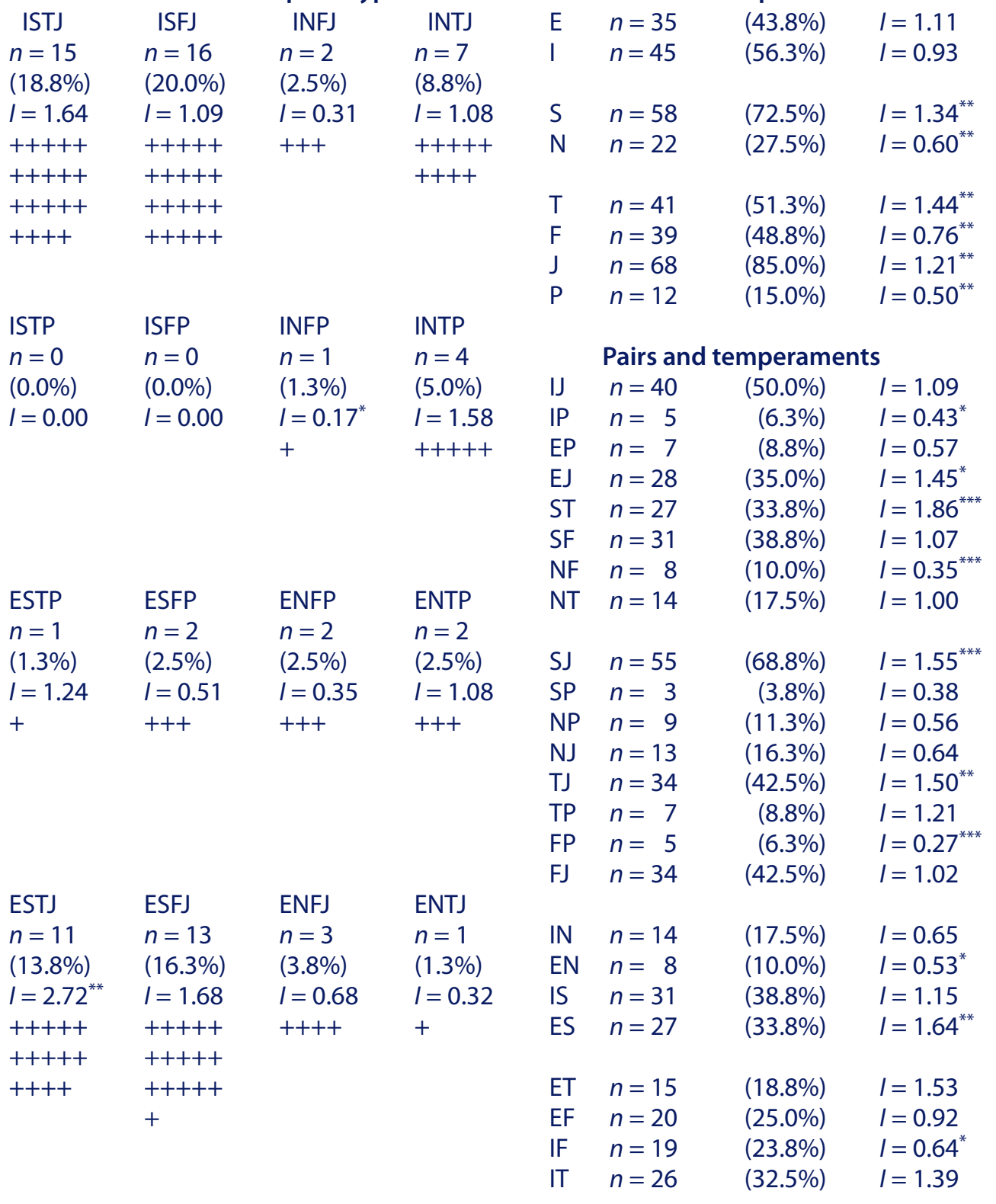

\begin{tabular}{lrrrlrrllllll}
\hline & \multicolumn{4}{c}{ Jungian types (E) } & \multicolumn{4}{c}{ Jungian types (I) } & \multicolumn{4}{c}{ Dominant types } \\
& $n$ & $\%$ & Index & & $n$ & $\%$ & Index & & $n$ & $\%$ & Index \\
E-TJ & 12 & 15.0 & 1.68 & I-TP & 4 & 5.0 & 1.28 & Dt.T & 16 & 20.0 & 1.56 \\
E-FJ & 16 & 20.0 & 1.32 & I-FP & 1 & 1.3 & $0.12^{* *}$ & Dt.F & 17 & 21.3 & 0.82 \\
ES-P & 3 & 3.8 & 0.63 & IS-J & 31 & 38.8 & 1.30 & Dt.S & 34 & 42.5 & 1.19 \\
EN-P & 4 & 5.0 & 0.53 & IN-J & 9 & 11.3 & 0.70 & Dt.N & 13 & 16.3 & 0.63 \\
\hline
\end{tabular}

Note: $N=80(\mathrm{NB}:+=1 \%$ of $N)$ ${ }^{*} p<.05,{ }^{* *} p<.01,{ }^{* * *} p<.001$ 
the local preachers; while $28 \%$ of the male ministers preferred the Apollonian Temperament (NF), the proportion fell to $10 \%$ among the local preachers.

Table 3 (see p. 21) presents the psychological type profile of the 62 female local preachers and compares them with the psychological type profile of the 311 female Methodist circuit ministers provided by Burton, Francis and Robbins (2010). The data will be discussed in two steps.

The first step discusses the psychological type profile of the female local preachers. In terms of the dichotomous preferences, they display equal preferences for introversion (50\%) and extraversion (50\%), and strong preferences for sensing (69\%) over intuition (31\%), for feeling (73\%) over thinking (27\%), and for judging (90\%) over perceiving (10\%). In terms of dominant type preferences, they display the following hierarchy: dominant sensing (39\%), dominant feeling (27\%), dominant intuition (21\%) and dominant thinking (13\%). In terms of the 16 complete types, the most frequently occurring types are ISFJ (26\%), ESFJ (21\%) and INFJ (11\%). In terms of psychological temperament preferences, the most frequently occurring temperament is SJ (66\%), followed by NF (23\%), NT (8\%) and SP (3\%).

The second step compares the psychological type profile of the female local preachers with the female Methodist circuit ministers published by Burton, Francis and Robbins (2010). In terms of the dichotomous preferences there are two significant differences between the two groups. While $52 \%$ of the female ministers preferred sensing, the proportion rose to $69 \%$ among the local preachers; while $70 \%$ of the female ministers preferred judging, the proportion rose to $90 \%$ among the local preachers. The differences in terms of the perceiving process are also reflected in the psychological temperament: while $43 \%$ of the female ministers preferred the Epimethean Temperament (SJ), the proportion rose to $66 \%$ among the local preachers; while $36 \%$ of the female ministers preferred the Apollonian Temperament (NF), the proportion fell to $23 \%$ among the local preachers.

\section{Conclusion}

This study set out to explore the similarities and dissimilarities between the psychological type and temperament profiles of Methodist local preachers and Methodist circuit ministers. It did so by assembling a new database provided by 142 local preachers ( 80 male and 62 female) who completed the Francis 
Table 3: Type distribution for female local preachers compared with female Methodist circuit ministers reported by Burton, Francis and Robbins (2010)

The sixteen complete types

\begin{tabular}{|c|c|c|c|c|c|c|c|}
\hline $\begin{array}{l}\text { ISTJ } \\
n=6 \\
(9.7 \%)\end{array}$ & $\begin{array}{l}\text { ISFJ } \\
n=16 \\
(25.8 \%)\end{array}$ & $\begin{array}{l}\text { INFJ } \\
n=7 \\
(11.3 \%)\end{array}$ & $\begin{array}{l}\text { INTJ } \\
n=2 \\
(3.2 \%)\end{array}$ & $\begin{array}{l}E \\
\text { I }\end{array}$ & $\begin{array}{l}n=31 \\
n=31\end{array}$ & $\begin{array}{l}(50.0 \%) \\
(50.0 \%)\end{array}$ & $\begin{array}{l}I=1.07 \\
I=0.94\end{array}$ \\
\hline$I=2.01$ & $I=1.34$ & $I=1.21$ & $I=0.84$ & $\mathrm{~S}$ & $n=43$ & (69.4\%) & $I=1.33^{* *}$ \\
\hline +++++ & +++++ & +++++ & +++ & $\mathrm{N}$ & $n=19$ & (30.6\%) & $I=0.64^{* *}$ \\
\hline \multirow[t]{5}{*}{ +++++ } & +++++ & +++++ & & & & & \\
\hline & +++++ & + & & $\mathrm{T}$ & $n=17$ & (27.4\%) & $I=1.20$ \\
\hline & +++++ & & & $\mathrm{F}$ & $n=45$ & (72.6\%) & $I=0.94$ \\
\hline & +++++ & & & & & & \\
\hline & + & & & $\begin{array}{l}J \\
P\end{array}$ & $\begin{array}{l}n=56 \\
n=6\end{array}$ & (90.3\%) & $\begin{array}{l}I=1.30^{* * *} \\
I=032^{* * *}\end{array}$ \\
\hline
\end{tabular}

$\begin{array}{llllrrrr}\text { ESTP } & \text { ESFP } & \text { ENFP } & \text { ENTP } & \text { NT } n=5 & (8.1 \%) & I=0.70 \\ n= & n=2 & n=3 & n=1 & & & & \\ (0.0 \%) & (3.2 \%) & (4.8 \%) & (1.6 \%) & \text { SJ } n=41 & (66.1 \%) & I=1.52^{* * *} \\ I=0.00 & I=0.72 & I=0.65 & I=0.84 & \text { SP } n=2 & (3.2 \%) & I=0.37 \\ & +++ & +++++ & ++ & \text { NP } n=4 & (6.5 \%) & I=0.30^{* *} \\ & & & & \text { NJ } n=15 & (24.2 \%) & I=0.93 \\ & & & & \text { TJ } n=16 & (25.8 \%) & I=1.61 \\ & & & & \text { TP } n=1 & (1.6 \%) & I=0.24 \\ & & & & \text { FP } n=5 & (8.1 \%) & I=0.34^{* *} \\ \text { ESTJ } & \text { ESFJ } & \text { ENFJ } & \text { ENTJ } & \text { FJ } n=40 & (64.5 \%) & I=1.21 \\ n=6 & n=13 & n=4 & n=2 & \text { IN } n=9 & (14.5 \%) & I=0.56 \\ (9.7 \%) & (21.0 \%) & (6.5 \%) & (3.2 \%) & \text { EN } n=10 & (16.1 \%) & I=0.73 \\ I=2.01 & I=1.45 & I=0.63 & I=1.25 & \text { IS } n=22 & (35.5 \%) & I=1.30 \\ +++++ & +++++ & +++++ & +++ & \text { ES } n=21 & (33.9 \%) & I=1.37 \\ +++++ & +++++ & ++ & & \text { ET } n=9 & (14.5 \%) & I=1.41 \\ & +++++ & & & \text { EF } n=22 & (35.5 \%) & I=0.97 \\ & +++++ & & & \text { IF } n=23 & (37.1 \%) & I=0.92 \\ & + & & & \text { IT } n=8 & (12.9 \%) & I=1.03\end{array}$

Pairs and temperaments

$\begin{array}{llrl}\text { IJ } & n=31 & (50.0 \%) & I=1.34 \\ \text { IP } & n=0 & (0.0 \%) & I=0.00^{* * *} \\ \text { EP } & n=6 & (9.7 \%) & I=0.65 \\ \text { EJ } & n=25 & (40.3 \%) & I=1.25 \\ \text { ST } & n=12 & (19.4 \%) & I=1.72 \\ \text { SF } & n=31 & (50.0 \%) & I=1.22 \\ \text { NF } & n=14 & (22.6 \%) & I=0.62^{*} \\ \text { NT } & n=5 & (8.1 \%) & I=0.70\end{array}$

SJ $n=41$

66.1\%) $\quad I=1.52^{* * *}$

(3.2\%) $\quad I=0.37$

(6.5\%) $\quad I=0.30^{* *}$

(24.2\%) $\quad I=0.93$

$25.8 \%) \quad I=1.61$

$(1.6 \%) \quad I=0.24$

(8.1\%) $\quad I=0.34^{* *}$

$(64.5 \%) \quad I=1.21$

14.5\%) $\quad I=0.56$

$(16.1 \%) \quad I=0.73$

(35.5\%) $\quad I=1.30$

Dominant types

\section{Jungian types (E)}

Jungian types (I)

n \% Index

n $\%$ Index

$\begin{array}{lrrllrrlllll}\text { E-TJ } & 8 & 12.9 & 1.74 & \text { I-TP } & 0 & 0.0 & 0.00 & \text { Dt.T } & 8 & 12.9 & 1.15 \\ \text { E-FJ } & 17 & 27.4 & 1.11 & \text { I-FP } & 0 & 0.0 & 0.00^{* *} & \text { Dt.F } & 17 & 27.4 & 0.75 \\ \text { ES-P } & 2 & 3.2 & 0.59 & \text { IS-J } & 22 & 35.5 & 1.47 & \text { Dt.S } & 24 & 38.7 & 1.31 \\ \text { EN-P } & 4 & 6.5 & 0.69 & \text { IN-J } & 9 & 14.5 & 1.10 & \text { Dt.N } & 13 & 21.0 & 0.93\end{array}$

Note: $N=62(\mathrm{NB}:+=1 \%$ of $N)$ ${ }^{*} p<.05,{ }^{* *} p<.01,{ }^{* * *} p<.001$ 
Psychological Type Scales (Francis 2005) and by setting these new data alongside the profiles of 693 male and 311 female Methodist circuit ministers compiled and published by Burton, Francis and Robbins (2010). The motivation for conducting this research stemmed from the recognition of the crucial role that local preachers continue to play in sustaining circuit ministry placed against the background of declining numbers of ordained ministers, and the dwindling strength of some local chapels.

In this context, psychological type theory and temperament theory may generate insight into the different and distinctive potentialities, strengths and weaknesses that Methodist circuit ministers and local preachers may bring to circuit ministry. From the range of detailed data generated by the study two particular findings are of particular salience and importance for appreciating the implications for the practical outcomes of sustaining the day-to-day and Sunday-to-Sunday ministry within local circuits. One of these findings is rooted in temperament theory and the other is rooted in psychological type theory.

In terms of temperament theory, the crucial finding concerns the place of the Epimethean (SJ) Temperament. In terms of men, the Epimethean (SJ) Temperament accounted for 31\% of Anglican priests, $44 \%$ of Methodist ministers, and $69 \%$ of local preachers. In terms of women, the Epimethean (SJ) Temperament accounted for $29 \%$ of Anglican priests, $43 \%$ of Methodist ministers, and $66 \%$ of local preachers. Oswald and Kroeger's (1988) conceptualisation of the Epimethean (SJ) Temperament as 'the conserving, serving pastor' crystallises both the strength and weakness of allowing this style of ministry to dominate. Here are devout and serious people deeply committed to the traditions that they have inherited and deeply committed to transmitting the traditions to those who follow them. They bring stability and continuity to the chapels that they are called to serve. Yet herein also lies the problem. They are not people likely to identify or to espouse new pathways to the future. Indeed they are likely to resist the very changes needed to secure that future.

Other strands of research have identified the Epimethean (SJ) Temperament as a strong character of church congregation, both in England (Francis, Robbins and Craig 2011) and in Australia (Robbins and Francis 2011). Indeed one of the battles often faced by Anglican clergy and by Methodist ministers alike concerns motivating congregations to see the point of the vision for change and development. In such battles the Epimethean local preacher may well be able to identify more readily with the congregation's voice than with the minister's voice. There are strengths and weaknesses in this situation, 
depending on whether the primary concern is to care for what remains from the past (and these people deserve care) or to envision a different future (and these visions may not always be attainable).

In terms of psychological type theory, the crucial finding concerns the judging process and the place of the thinking function within evaluation and decisionmaking. While the feeling function privileges the importance of subjective personal and interpersonal values and the goals of harmony and peace, the thinking function privileges the importance of objective and impersonal logic and the goals of truth and fairness. There are, moreover, important sex differences in predicting the preferences for thinking and for feeling. According to the UK psychological type population norms published by Kendall (1998), while $70 \%$ of women prefer feeling, $65 \%$ of men prefer thinking. As a consequence feeling may be conceptualised as a feminine orientation while thinking may be conceptualised as a masculine orientation. In terms of women, the feeling function accounts for $74 \%$ of Anglican priests, $77 \%$ of Methodist ministers, and $73 \%$ of local preachers. The picture is consistent. In terms of men, the feeling function accounts for $54 \%$ of Anglican priests, $64 \%$ of Methodist ministers, and $49 \%$ of local preachers. The picture suggests that the ministry of local preachers may be accessing and drawing on a wider and (slightly) more representative pool of men. They are more likely than the ministers to wish to grasp the nettle and to sort out problems in the local chapel, whether or not it disrupts long-seated relationships.

Other strands have identified church congregations to be strongly comprised of feeling types, both in England (Francis, Robbins and Craig 2011) and in Australia (Robbins and Francis 2011). Methodist ministers feel more at home than local preachers in appreciating the dynamics of communities so dominated by the feeling preference. Yet at times the ministers may be unable or feel reluctant to deal with the underlying issues and tensions that may be disruptive (and indeed unhealthy) within such communities. The right chosen local preacher may help to find a way through such issues.

The weakness with the present study concerns the small (and possibly unrepresentative) nature of the sample of local preachers, especially when considered alongside the systematic survey of the Methodist circuit ministers reported by Burton, Francis and Robbins (2010). The findings, however, carry sufficiently important practical implications for the effective delivery of Methodist circuit ministry to make worthwhile a more systematic replication study among local preachers. 


\section{Bibliography}

Bigelow, E. D., Fitzgerald, R., Busk, P., Girault, E. and Avis, J. 1988. 'Psychological Characteristics of Catholic Sisters: Relationships between the MBTI and Other Measures', Journal of Psychological Type 14: 32-36.

Burns, J., Francis, L. J., Village, A. and Robbins, M. 2013. 'Psychological Type Profile of Roman Catholic Priests: An Empirical Enquiry in the USA', Pastoral Psychology 62: 239-246. doi.org/10.1007/s11089-012-0483-7

Burton, L., Francis, L. J. and Robbins, M. 2010. 'Psychological Type Profile of Methodist Circuit Ministers in Britain: Similarities with and Differences from Anglican Clergy', Journal of Empirical Theology 23: 64-81. doi.org/10.1163/157092510X503020

Cabral, G. 1984. 'Psychological Types in a Catholic Convent: Applications to Community Living and Congregational Data', Journal of Psychological Type 8: 16-22.

Craig, C. L., Duncan, B. and Francis, L. J. 2006. 'Psychological Type Preferences of Roman Catholic Priests in the United Kingdom', Journal of Beliefs and Values 27: 157-164. doi.org/10.1080/13617670600849812

Craig, C. L., Horsfall, T. and Francis, L. J. 2005. 'Psychological Types of Male Missionary Personnel Training in England: A Role for Thinking Type Men?', Pastoral Psychology 53: 475-482. doi.org/10.1007/s11089-005-2588-8

Francis, L. J. 2005. Faith and Psychology: Personality, Rreligion and the Individual. London: Darton, Longman and Todd.

Francis, L. J., Craig, C. L., Horsfall, T. and Ross, C. F. J. 2005. 'Psychological Types of Male and Female Evangelical Lay Church Leaders in England, Compared with United Kingdom Population Norms', Fieldwork in Religion 1: 69-83.

Francis, L. J., Craig, C. L., Whinney, M., Tilley, D. and Slater, P. 2007.'Psychological Profiling of Anglican Clergy in England: Employing Jungian Typology to Interpret Diversity, Strengths, and Potential Weaknesses in Ministry', International Journal of Practical Theology 11: 266-284. doi.org/10.1515/IJPT.2007.17

Francis, L. J., Gubb, S. and Robbins, M. 2009. 'Psychological Type Profile of Lead Elders within the Newfrontiers Network of Churches in the United Kingdom', Journal of Beliefs and Values 30: 61-69. doi.org/10.1080/13617670902784568

Francis, L. J., Jones, S. H. and Robbins, M. 2014. 'The Psychological Type Profile of Readers in the Church of England: Clones of the Clergy or Distinctive Voices?', Journal of Anglican Studies 12: 165-184. doi.org/10.1017/S1740355313000077

Francis, L. J., Nash, P., Nash, S. and Craig, C. L. 2007. 'Psychology and Youth Ministry: Psychological Type Preferences of Christian Youth Workers in the United Kingdom', Journal of Youth Ministry 5(2): 73-90.

Francis, L. J. and Payne, V. J. 2002. 'The Payne Index of Ministry Styles (PIMS): Ministry Styles and Psychological Type among Male Anglican Clergy in Wales', Research in the Social Scientific Study of Religion 13: 125-141.

Francis, L. J., Payne, V. J. and Jones, S. H. 2001. 'Psychological Types of Male Anglican Clergy in Wales', Journal of Psychological Type 56: 19-23.

Francis, L. J., Penson, A. W. and Jones, S. H. 2001. 'Psychological Types of Male and Female Bible College Students in England', Mental Health, Religion and Culture 4: 23-32. doi.org/10.1080/13674670123953 
Francis, L. J. and Robbins, M. 2002. 'Psychological Types of Male Evangelical Church Leaders', Journal of Belief and Values 23: 217-220. doi.org/10.1080/ 1361767022000010860

Francis, L. J., Robbins, M. and Craig, C. L. 2011. 'The Psychological Type Profile of Anglican Churchgoers in England: Compatible or Incompatible with Their Clergy?', International Journal of Practical Theology 15: 243-259. doi.org/10.1515/ IJPT.2011.036

Francis, L. J., Robbins, M. and Wulff, K. 2011. 'Psychological Type Profile of Male and Female Clergy Serving in the Presbyterian Church (USA): Implications for Strengths and Weaknesses in Ministry', Research in the Social Scientific Study of Religion 22: 192-211.

Francis, L. J. and Village, A. 2012. 'The Psychological Temperament of Anglican Clergy in Ordained Local Ministry (OLM): The Conserving, Serving Pastor?', Journal of Empirical Theology 25: 57-76. doi.org/10.1163/157092512X635743

Greenfield, M. 1969. 'Typologies of Persisting and Non-Persisting Jewish Clergymen', Journal of Counselling Psychology 16: 368-372. doi.org/10.1037/h0027708

Haley, J. M. and Francis, L. J. 2006. British Methodism: What Circuit Ministers Really Think. Peterborough: Epworth.

Harbaugh, G. L. 1984. 'The Person in Ministry: Psychological Type and the Seminary', Journal of Psychological Type 8: 23-32.

Holsworth, T. E. 1984. 'Type Preferences among Roman Catholic Seminarians', Journal of Psychological Type 8: 33-35.

Irvine, A. R. 1989. 'Isolation and the Parish Ministry', unpublished doctoral dissertation, University of St Andrews.

Jung, C. G. 1971. Psychological Types: The Collected Works, volume 6. London: Routledge and Kegan Paul.

Kay, W. K. and Francis, L. J. 2008. 'Psychological Type Preferences of Female Bible College Students in England', Journal of Beliefs and Values 29: 101-105. doi.org/10.1080/ 13617670801928324

Kay, W. K., Francis, L. J. and Craig, C. L. 2008. 'Psychological Type Preferences of Male British Assemblies of God Bible College Students: Tough Minded or Tender Hearted?', Journal of the European Pentecostal Theological Association 28: 6-20. doi.org/10.1179/jep.2008.28.1.002

Kay W. K., Francis, L. J. and Robbins M. 2011. 'A Distinctive Leadership for a Distinctive Network of Churches? Psychological Type Theory and the Apostolic Networks', Journal of Pentecostal Theology 20: 306-322. doi.org/10.1163/174552511X597170 Keirsey, D. and Bates, M. 1978. Please Understand Me. Del Mar, CA: Prometheus Nemesis. Kendall, E. 1998. Myers-Briggs Type Indicator: Step 1 Manual Supplement. Palo Alto, CA: Consulting Psychologists Press.

McCaulley, M. H. 1985. 'The Selection Ratio Type Table: A Research Strategy for Comparing Type Distributions,' Journal of Psychological Type 10: 46-56.

Macdaid, G. P., McCaulley, M. H. and Kainz, R. I. 1986. Myers-Briggs Type Indicator: Atlas of Type Tables. Gainesville, FL: Center for Application of Psychological Type Inc. Methodist Church. 2017. Methodist connexion statistics, personal communication. 
Milburn, G. and Batty, M. 1995. Workaday Preachers. Peterborough: Methodist Publishing House.

Myers, I. B. and McCaulley, M. H. 1985. Manual: A Guide to the Development and Use of the Myers-Briggs Type Indicator. Palo Alto, CA: Consulting Psychologists Press.

Oswald, R. M. and Kroeger, O. 1988. Personality Type and Religious Leadership. Washington, DC: The Alban Institute.

Robbins, M. and Francis, L. J. 2011. 'All are Called, but Some Psychological Types are More Likely to Respond: Profiling Churchgoers in Australia', Research in the Social Scientific Study of Religion 22: 213-229. doi.org/10.1163/ej.9789004207271. i-360.44

Royle, M. H., Norton, J. and Larkin, T. 2015. 'Psychological Type Profile of Clergywomen and Clergymen serving in the New York Metropolitan Area of the Reformed Church in America', Mental Health, Religion and Culture 18: 586-592. doi.org/ 10.1080/13674676.2014.961264

Sawkins, J. 2002. Methodist Local Preachers in Great Britain. A Millennial Profile. Edinburgh: Heriot Watt University. 